\title{
Coral recruitment and potential recovery of eutrophied and blast fishing impacted reefs in Spermonde Archipelago, Indonesia
}

\author{
Yvonne Sawall $^{\mathrm{a}, *, 1}$, Jamaluddin Jompa $^{\mathrm{b}}$, Magdalena Litaay ${ }^{\mathrm{b}}$, Andi Maddusila ${ }^{\mathrm{b}}$, Claudio Richter ${ }^{\mathrm{c}}$ \\ a Leibniz Center for Tropical Marine Ecology, Fahrenheitstr. 6, 28359 Bremen, Germany \\ ${ }^{\mathrm{b}}$ Center for Coral Reef Research, Hasanuddin University, Jl. Perintis Kemerdekaan km 10, Makassar 90245, Indonesia

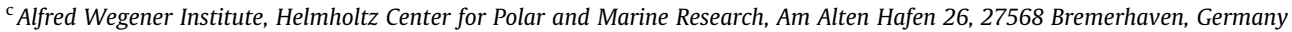

\section{A R T I C L E I N F O}

\section{Keywords:}

Coral recruitment

Seasonality

Eutrophication

Blast fishing

Spermonde Archipelago

\begin{abstract}
A B S T R A C T
Coral recruitment was assessed in highly diverse and economically important Spermonde Archipelago, a reef system subjected to land-based sources of siltation/pollution and destructive fishing, over a period of 2 years. Recruitment on settlement tiles reached up to 705 spat $\mathrm{m}^{-2} \mathrm{yr}^{-1}$ and was strongest in the dry season (July-October), except off-shore, where larvae settled earlier. Pocilloporidae dominated nearshore, while a more diverse community of Acroporidae, Poritidae and others settled in the less polluted mid-shelf and off-shore reefs. Non-coral fouling community appeared to hardly influence initial coral settlement on the tiles, although, this does not necessarily infer low coral post-settlement mortality, which may be enhanced at the near- and off-shore reefs as indicated by increased abundances of potential space competitors on natural substrate. Blast fishing showed no local reduction in coral recruitment and live hard coral cover increased in oligotrophic reefs, indicating potential for coral recovery, if managed effectively.
\end{abstract}

(c) 2013 Elsevier Ltd. All rights reserved.

\section{Introduction}

Recruitment is a key factor in the recovery of coral communities after disturbance, e.g. mortalities following mass bleaching events (Tamelander, 2002), storms (Connell et al., 1997; Coles and Brown, 2007) or tsunamis (Sawall et al., 2010). The assessment of coral recruitment patterns is therefore of high importance for coral reef management (Connell et al., 1997; Glassom et al., 2004; Fox, 2004). Recruitment patterns are known to be influenced by a wide range of factors, inter alia fecundity and spawning of the adults, fertilization success of the gametes, dispersal and survival of the larvae, settlement, metamorphosis and post-settlement survival, which are further influenced by a variety of extrinsic factors.

Gamete development and spawning are initiated by certain environmental conditions, hence spawning is often synchronized, triggered by the calm season (van Woesik, 2010), increasing temperature (Shlesinger and Loya, 1985; Gleason, 1996; Guest et al., 2005) and/or by a particular moon phase (Richmond and Hunter, 1990). One of the advantages of spawning during the calm season, which usually coincides with low precipitation, low river run-off and low nutrient supply to coastal waters, may be in the lower abundance of space competitors that are competitively superior

\footnotetext{
* Corresponding author. Tel.: +49 (0)431 600 4577; fax: +49 (0)431600 1671.

E-mail address: ysawall@geomar.de (Y. Sawall).

1 Current address: Helmholtz Center for Ocean Research, Wischhofstr. 1-3, 24148 Kiel, Germany.
}

in nutrient-enriched waters (algae, fast-growing ascidians, barnacles and other opportunistic fouling organisms; Birkeland, 1977; Glassom et al., 2004). Larval dispersal depends on the competency period of the larvae and the prevailing small (within reef) and large-scale currents (between reefs) (Sammarco and Andrews, 1989; Black et al., 1990) and larvae settlement and metamorphosis depend on the availability and suitability of substrate, which is supportive if heterogeneous, non-moving and biologically preconditioned (Fox et al., 2003; Webster et al., 2004; Petersen et al., 2005; Sawall et al., 2010). After metamorphosis and initial growth, survival may further dependent on water quality, light environment and abundance of potential space competitors and predators (Birkeland, 1977; Abelson et al., 2005; Ferse, 2008). Hence, initial larval supply does not necessarily need to result in high recruitment success, and coral recruitment patterns can vary substantially at various spatial scales, leading to considerable fine(within reef) and mesoscale (near- vs. off-shore) patchiness.

Anthropogenic impacts may have significant negative effects on natural recruitment patterns in corals (Tomascik, 1991; Abelson et al., 2005). Eutrophication, pollution and sedimentation were found to hamper gamete production, alter the timing of spawning and decrease the fertilization success (Gilmour, 1999; Loya et al., 2004). They were found to slow the development and metamorphosis of the larvae and decrease the survival of the coral recruits (Gilmour, 1999; Hughes and Connell, 1999; Abelson et al., 2005). Eutrophication is also known to foster the growth of potential space competitors of coral recruits (Tomascik, 1991; Dunstan and 
Johnson, 1998; Abelson et al., 2005), toxic cyanobacteria or macroalgae inhibiting coral larvae settlement (Kuffner and Paul, 2004). Sedimentation is known to hamper larvae settlement and to smother coral recruits (Hodgson, 1990). Another common human impact on coral reefs is overfishing and deleterious fishing practices such as blast and cyanide fishing. Overfishing could lead to a significant decimation of grazers, which control e.g. algae growth, hence controlling potential space competitor for coral recruits (Hughes and Connell, 1999). Furthermore, reef destruction through blast fishing was shown to increase the proportion and spatial extent of coral rubble, which because of its low resistance to physical dislodgement by waves and currents may provide a killing field for coral spat (Harrison and Wallace, 1990; Fox et al., 2003).

The Spermonde Archipelago in SW Sulawesi is one of the most diverse but also one of the most endangered coral reef regions of the world, located in the center of the Coral Triangle. The archipelago harbors diverse coral reefs but also supports an important part of the reef fishery in Indonesia for a growing coastal population (Pet-Soede et al., 1999). As a result, the archipelago is subjected to the combined impacts of destructive fishing (blast and cyanide fishing), overfishing and land run-off (eutrophication, pollution and sedimentation), which have collectively taken their toll on reef structure and function (Edinger et al., 1998; Pet-Soede et al., 1999).

Although Spermonde is one of the best studied reef systems in Indonesia, with detailed studies on reef distribution and biodiversity (e.g., Moll, 1983; Renema and Troelstra, 2001; Cleary et al., 2005), population dynamics (e.g., Knittweis et al., 2009) and coral physiology (Sawall et al., 2011), so far nothing is known about coral recruitment, in spite of reef monitoring and management activities over many years (e.g., COREMAP).

The aim of this study was to assess early recruitment patterns as a function of seasonality, abundance of potential competitors, and occurrence of anthropogenic stressors (eutrophication and localized blast fishing). This is expected to elucidate the dynamics, resilience and recovery potential of corals in one of the most diverse but also one of the most exploited coral reef regions worldwide.

\section{Material and methods}

\subsection{Study sites}

The study was conducted in the Spermonde Archipelago, SWSulawesi, Indonesia, featuring 100 coral-fringed small islands scattered across a $40 \mathrm{~km}$ wide carbonate shelf (Fig. 1). Most reefs are well developed in the south, west and north faces of the island, with conspicuous reef gaps on the sandy steeper areas of the eastern sides (Moll, 1983). The shelf depth ranges from $10 \mathrm{~m}$ (near-shore) to $40 \mathrm{~m}$ (off-shore). The predominant current is consistent with the throughflow in the Makassar Strait directed from N to S year around (Storm, 1989). The near-shore reefs which are subjected to the run-off of rivers north and south of the city of Makassar carrying untreated waste water and industrial pollution from the 1.5 million inhabitants along with agricultural run-off feature only low coral cover and diversity (Edinger et al., 1998; Renema and Troelstra, 2001). The near midshelf reefs are still affected by the land run-off during the wet season (November to February), but also by local waste water discharge in some of the populated islands (Edinger et al., 1998; Renema and Troelstra, 2001). The remote mid-shelf and off-shore reefs near the shelf edge are mainly exposed to oligotrophic waters, with oceanic conditions and seasonal upwelling from Makassar Strait at the margins (Ilahude, 1978).

Seasonality is characterized by the wet NW-monsoon from November to February (wet, in the following), a transition period from wet to dry season between March and June (trans) and the

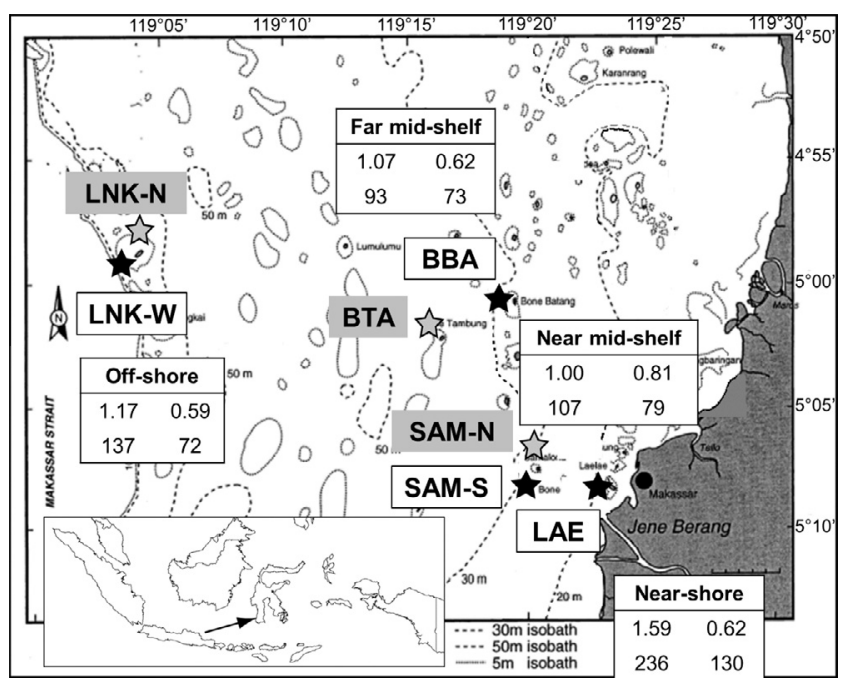

Fig. 1. Map of Spermonde Archipelago with the high (grey) and low (black) blast fishing impacted study sites: near-shore Lae Lae (LAE), near mid-shelf Samalona South (SAM-S) and Samalona North (SAM-N), far mid-shelf Bonebatang (BBA) and Bonetambung (BTA), off-shore Lanyukan West (LNK-W) and Lanyukan North (LNK$\mathrm{N})$. Parameters of water quality in tables: concentration $\left[\mu \mathrm{g} \mathrm{l}^{-1}\right]$ of chlorophyll $a$ (upper values) in February (left) and June (right), particulate organic carbon (lower values) in February (left) and June (right). Standard deviation for chlorophyll $a$ between 0.04 and 0.33, and for particulate organic carbon between 2 and 20 (Sawall et al., 2012)

dry SE-monsoon from July to October (dry). Rainfall peaks in January with about $730 \mathrm{~mm} \mathrm{month}^{-1}$ and is lowest in August with $15 \mathrm{~mm} \mathrm{month}^{-1}$ (average data for 1961-1990, World Meteorological Organization, Geneva, Switzerland). Destructive fishing is common in Spermonde. Blast fishing leaves scars of coral rubble craters, which are consequently overgrown by macroalgae in some areas (Pet-Soede and Erdmann, 1998, pers. observ.). Reefs were classified as highly impacted with regard to blast fishing, if craters of coral rubble with a size of $5-15 \mathrm{~m}$ in diameter were evident and if those contributed with a minimum of $30 \%$ to the benthic cover. Seven study sites were chosen along a cross-shelf transect and classified into four different shelf zones distinguished by distance to shore and associated degree of eutrophication based on chlorophyll $a$ and particulate organic carbon concentrations in the water (Fig. 1): (1) Near-shore (Lae Lae - LAE), (2) near mid-shelf (Samalona South - SAM-S, Samalona North - SAM-N) (3) far mid-shelf (Bonebatang - BBA, Bonetambung - BTA) and (4) off-shore (Lanyukan West - LNK-W, Lanyukan North - LNK-N). Each zone included a low and highly impacted reef by blast fishing, except for nearshore with a low impacted reef only (Fig. 1).

\subsection{Characterization of the benthic community}

Permanent line intercept transects (English et al., 1997) were conducted in order to assess the benthic community structure in November 2007, 2008 and 2009. A measuring tape was laid out over $60 \mathrm{~m}$ along the reef edge in $3 \mathrm{~m}$ depth and the underlying substrate was recorded to the nearest $\mathrm{cm}$, always by the same investigator (YS). The following substrate categories were distinguished: live hard coral, dead coral $(>15 \mathrm{~cm})$, coral rubble $(<15 \mathrm{~cm})$, sand, macroalgae and others. The latter included soft corals, sponges, anemones, ascidians, hydrozoans and bivalves. The percentage contribution of each category was calculated.

\subsection{Coral recruitment}

Coral recruitment was monitored over 2 years from November 2007 until October 2009 on settlement tiles deployed at all 7 reef 
sites arranged along a cross-shelf gradient, subjected to moderate and heavy blast fishing (see above). For the near-shore site LAE, no data are available for the first year. Settlement tiles, deployed in 3-4 $\mathrm{m}$ depth along the reef edge, were revisited every 4 months in order to detect changes between wet, transition and dry seasons. Terracotta tiles (Harriott and Fisk, 1987; Maida et al., 1995; Dunstan and Johnson, 1998) $(15 \times 15 \mathrm{~cm})$ were connected pairwise by a stainless steel bolt, with the unglazed faces exposed and the glazed faces touching each other ( $n=16$ tile pairs for each site). The bolt holding the tiles was fixed at an angle of $45^{\circ}$ on dead coral boulders. This arrangement prevented the accumulation of sediments on the tiles (English et al., 1997) and it allowed the distinction of upper (light-exposed) and lower (shaded) faces for organism settlement (see Electronic Supplementary Material, ESM Fig. S1). The tiles were replaced every 4 months (end of February, June, October), except for BBA during the first season (I), where, for logistic reasons, the tiles had to be replaced 1 month later (end of March). After collection, the tiles were dried in the sun and examined under a dissection microscope.

Coral spat were identified to the family level after Babcock et al. (2003), distinguishing between Pocilloporidae, Acroporidae, Poritidae and "unidentified" spat. The fouling community was described by visually estimating the cover of filamentous algae, crustose coralline red algae, bryozoans, sponges and ascidians to the closest $5 \%$, as well as by the abundance (No. tile ${ }^{-1}$ ) of barnacles, spirorbid worms and bivalves. Identification and quantification was done by the same investigator (YS) throughout the study to avoid bias between investigators.

\subsection{Data analyses}

Multivariate analyses were performed in order to analyze spat and fouling community patterns as a function of blast fishing impact, tile exposure (upper and lower face), seasonality and crossshelf variation (shelf zones), using the software Primer v6 and the add-on software PERMANOVA+ (Clarke and Gorley, 2006; Anderson et al., 2008).

First, a Bray-Curtis similarity matrix was calculated with the coral spat and the fouling community data each, considering one tile pair as one sample. To include zero-value data (i.e., spat-free tiles) in the analyses, a "dummy" variable was created for the spat data (Clarke et al., 2006), i.e. an additional spat family column with the value " 1 " for all rows. The resulting zero-adjusted Bray-Curtis similarity matrix allows including absence data into the analysis with minimal distortion of the overall recruitment patterns (abundance and composition of coral spat over time and space) described by the distances between the samples (Clarke et al., 2006). The fouling community data were standardized prior to the analyses to eliminate the effect of different units (\% and individual counts) according to Clarke and Gorley (2006). One-way analyses of similarity (ANOSIM) were conducted to assess possible differences between coral spat communities and between fouling communities considering the factors blast fishing impact, seasonality, year and shelf zone. To assess differences with respect to tile exposure, the Bray-Curtis similarity matrix was calculated with each single tile as one sample (instead of tile pair), following than the same procedure as described above. Subsequent analyses of similarity percentage (SIMPER) were conducted in order to determine, which of the coral spat or fouling taxa contributed most to the dissimilarities between seasons or shelf zones, respectively.

To assess potential competition/facilitation effects of the fouling community on the coral spat community, a distance-based redundancy analysis (dbRDA) was performed (Anderson et al., 2008). This routine is based on multivariate multiple regression performed between the response variable (here: coral spat community structure with its resemblance matrix calculated after Bray
Curtis) and the predictor variables (here: fouling organisms). The results are presented in an ordination space (biplot), where the synthetic axes represent the direction of maximum explained variation by the predictor variables and the lines (vectors) the direction and relative importance (length of the vector) of a given variable.

\section{Results}

\subsection{Benthic community structure}

Live hard coral cover, initially ranging between $10 \%$ (far midshelf BTA) and 34\% (off-shore LNK-W and LNK-N), increased between Nov 2007 and Nov 2009 to values between 18\% (near-shore LAE) and 53\% (near mid-shelf SAM-S) and decreased off-shore to a slightly lower value at LNK-W (32\%) to almost a $10 \%$-reduction at LNK-N (25\%) (Fig. 2). The most dramatic increases with $20 \%$ occurred at near mid-shelf SAM-S and at both far mid-shelf reefs (BBA and BTA) (Fig. 2). Coral rubble in the blast fishing affected reefs (SAM-N, BTA, LNK-N) made up $38-56 \%$ of the available substrate in November 2007 , but only $4-27 \%$ in the other reefs (Fig. 2). At off-shore LNK-N about half of the coral rubble was covered by macroalgae (e.g. Halimeda, Laurencia). Rubble cover decreased over time at the blast fishing affected reefs, particularly at far mid-shelf BTA, where values dropped from $56 \%$ to $42 \%$ concomitantly with the increase of live hard coral cover. Dead coral cover varied initially around $20 \%$ at all sites where monitoring started in November 2007, but was as high as 39\% at near-shore LAE where monitoring started in November 2008 (Fig. 2). A decrease in dead coral cover over the experimental time span was strongest at LAE (39-25\%), concomitantly with the increase in various filter feeding organisms including clams, ascidians, sponges and hydrozoans from $28 \%$ to $34 \%$ (cf. "Others"), and an increase in sand cover from $10 \%$ to $17 \%$ (Fig. 2). The strongest increase in dead coral cover was evident at the blast-fishing impacted offshore reef LNK-N from $14 \%$ to $26 \%$, while live hard coral cover decreased (Fig. 2). The abundance of organisms within the category "Others" remained below $10 \%$ at all sites, except LAE (Fig. 2).

\subsection{Coral spat abundances and its relation to blast fishing impact}

A total of 1058 tiles was investigated (some were lost), with a total of 2315 coral spat. The variation in spat densities was high, ranging from 0 to 38 spat tile ${ }^{-1}$ (each tile equivalent to $225 \mathrm{~cm}^{2}$ ). 360 of the upper tiles and 187 of the lower tiles did not harbor any coral spat. On the lower tiles, larvae preferably but not exclusively settled close to the tile edge and on the upper tiles, directly on the tile edge. The spat size varied between 0.5 and $4 \mathrm{~mm}$ in diameter. Annual larvae spat fall was highest in LAE (705 spat $\left.\mathrm{m}^{-2} \mathrm{yr}^{-1}\right)$, followed by BBA $(686 \pm 57)$, BTA $(597 \pm 157)$, SAM-N (545 \pm 19$)$, LNK-W $(469 \pm 81)$, LNK-N $(403 \pm 223)$ and SAM-S $(286 \pm 70)$. The coral spat community was dominated by Pocilloporidae (63\% of all spat), followed by Acroporidae (14.6\%), Poritidae (7.8\%) and others (14.6\%) (Fig. 3). No general relationship between blast fishing on either coral spat community or fouling community could be detected (Table 1 ).

\subsection{Coral spat and fouling community on upper versus lower tiles}

There were pronounced differences in spat densities and fouling community composition between the upper and lower tile faces (Table 1). Spat densities were strongly elevated on the lower face, where the fouling community was most diverse and structurally complex. On the upper face, spat densities were low, except at near-shore LAE and the fouling community was comparatively 


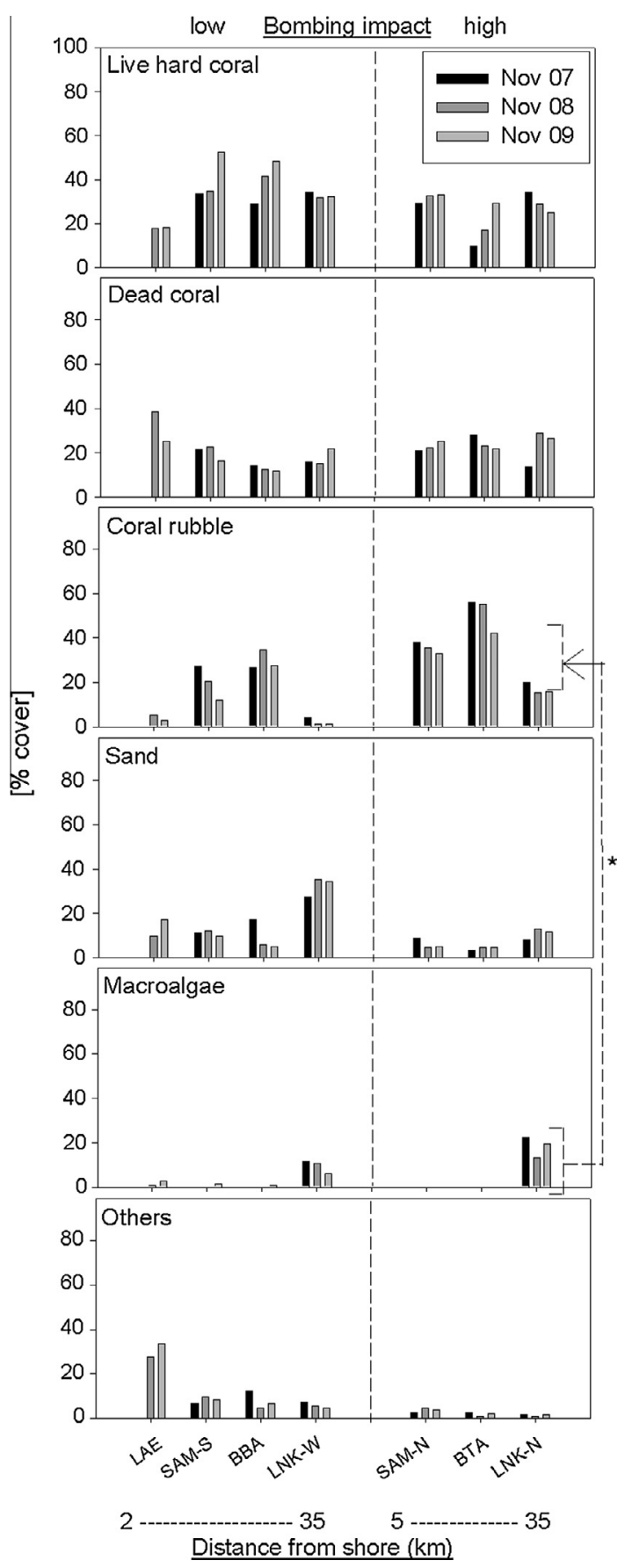

Fig. 2. Benthic composition in\% cover. * Observed macroalgae growth occurred on coral rubble.

homogenous consisting mainly of filamentous and crustose coralline red algae (Figs. 3 and 4 ).

\subsection{Seasonal variation in coral spat and fouling community structure}

Seasonal differences were pronounced in spat abundances, in particular between the wet season (I + IV) and the other two seasons (trans: II + V and dry: III + VI) (Table 1). Spat densities were lowest on tiles from the wet season (all sites combined: $45.5 \pm 50.9$ spat $\mathrm{m}^{-2}$ [mean $\left.\pm \mathrm{SD}\right]$ ), intermediate in the transition period (146.2 \pm 49.5$)$ and highest in the dry season, between July and October $(321.8 \pm 160.0)$. The difference between the seasons was mostly explained by an increase in Pocilloporidae from the wet to the dry season (SIMPER, contribution to dissimilarity 23$38 \%$ ), followed by Acroporidae (9-12\%). Seasonality was less pronounced in the fouling community, with smaller but significant differences, again between the wet season and the other two seasons (Table 1). This was mostly due to variability in filamentous (SIMPER, contribution to dissimilarity 12-13\%) and crustose algae abundance (10-11\%).

Although inter-annual differences in spat fall density and fouling community structure could not be statistically detected overall (Table 1 ), they were found locally, e.g. at SAM-S, where strongly elevated Poritidae densities occurred in the second year (seasons IV-VI) compared to the first year (seasons I-III), while the opposite was found in SAM-N (Fig. 3). At BBA, higher Acroporidae and lower Pocilloporidae densities occurred in the first year compared to the second year, while the reverse pattern was evident in BTA (Fig. 3).

\subsection{Spatial differences in coral spat and fouling community structure}

Cross-shelf differences in the spat community were small but significant between near-shore and near mid-shelf and between near-shore and off-shore (Table 1 ). This was mostly due to a shift from Pocilloporidae near-shore to Acroporidae spat mid-shelf and off-shore, but also due to the paucity of Poritidae near-shore compared to the other shelf zones (Fig. 3). In contrast to the spat, the fouling community revealed much stronger spatial differences, particularly between the near and off-shore reefs (Table 1 ). These differences were mostly explained by a shift from filamentous algae to crustose coralline red algae and a decrease in spirorbid worms from near- to off-shore (SIMPER, contribution to dissimilarity $15 \%, 12 \%$ and $12 \%$ respectively, Fig. 4). Barnacles were more abundant close to shore, while bryozoans and bivalves were found mostly further away from shore (Fig. 4).

Differences in the seasonality of recruitment patterns were observed between the coral families along the cross-shelf transect (Fig. 3). While Pocilloporidae revealed the highest spat densities during the dry season in all shelf zones, Poritidae (and to a lesser degree Acroporitidae) revealed highest spat densities already during the transition period in off-shore LNK-W/LNK-N (Fig. 3).

\subsection{Relationship between coral spat and fouling community}

Distance-based redundancy analysis revealed only weak links between the coral spat community structure and the fouling community (Fig. 5). With only $23.6 \%$ of the variation in the spat community explained by the two axes (dbRDA 1 and 2), fouling is a weak predictor of coral recruitment pattern. For dbRDA 1, barnacles and bryozoans contributed most to the variation, which were both higher during the wet season (vectors pointing into the direction of the filled symbols, Fig. 5), when coral spat abundances were low. In contrast, the spatial variation in the spat community structure could hardly be explained by one of the presented axes, although a separation of different shelf zones are represented by the dbRDA, in particular for the near mid-shelf reefs (light green, Fig. 5). However, barnacles and crustose coralline algae revealed slight relationships to cross-shelf variation in the coral spat community, where barnacle abundances were higher mid-shelf (near and far) and coralline algae higher off-shore (Fig. 5).

\section{Discussion}

\subsection{Temporal variation - seasonality}

The seasons in Spermonde Archipelago are determined by the rate of precipitation and land run-off during the wet NW monsoon (December-February) and the dry SE monsoon (June-September). 


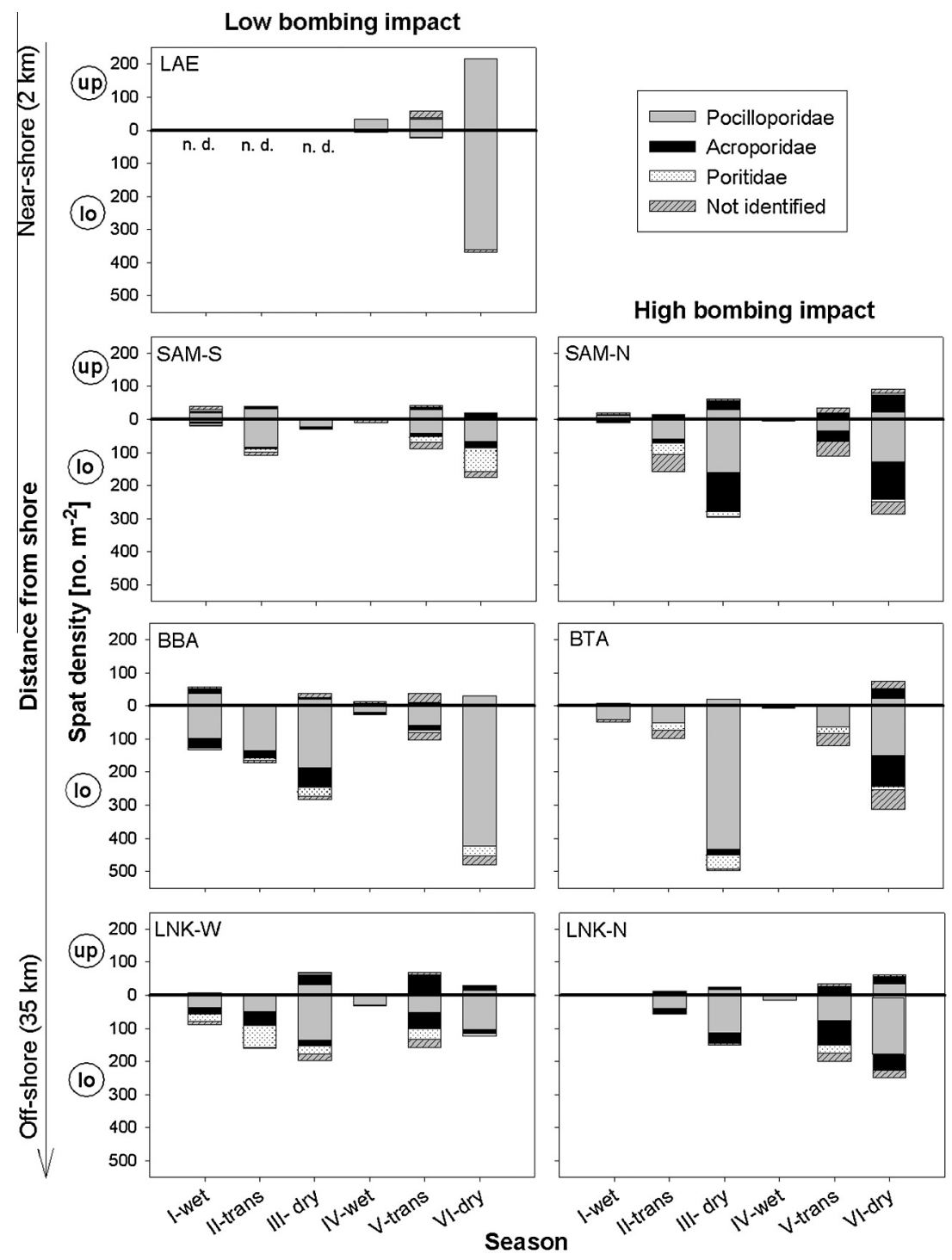

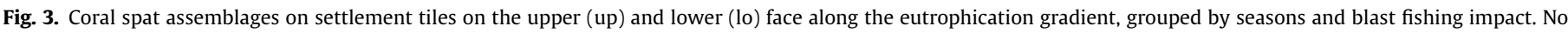
data available (n.d.).

Spawning events were suggested for the majority of Spermonde corals between March and April (before the dry season), based on findings of oocyte maturity of several broadcast spawners (Baird et al., 2009). While the suggested spawning period explains increased Acroporidae spat densities off-shore on tiles of the transition period, it appears to be too early to explain the peaks in spat densities of near-shore and mid-shelf reefs on tiles of the dry season, assuming settlement of larvae within several days after spawning (Harrison and Wallace, 1990). While it is unknown, where exactly the study of Baird et al. (2009) was carried out in the Spermonde Archipelago, there is one possible reason for a cross-shelf shift in spawning. Off-shore upwelling of colder, low oxygen and nutrient enriched deep water from the Makassar Strait was previously described to occur in August (Ilahude, 1978), which might hamper coral recruitment success and hence leading to an earlier onset of reproduction in off-shore corals. However during the period of this study, no indication for upwelling was found, e.g. decreased SST (no obvious cross-shelf variability in SST, variation throughout the year: $26-30^{\circ} \mathrm{C}$; NASA - Giovanni online 200709). Cross-shelf variability in reproduction was also observed in the Great Barrier Reef, albeit in the opposite direction, where near-shore corals spawned 1 month earlier than off-shore corals possibly due to higher temperatures near-shore $\left(\sim 1^{\circ} \mathrm{C}\right.$, Willis et al., 1985). The Spermonde off-shore pattern is similar to the recruitment pattern found in Manado, $1000 \mathrm{~km}$ north of Spermonde off North Sulawesi with a similar climate. Here, highest coral recruit numbers were found on tiles collected in June and July after 3 months of deployment (Ferse, 2008; Romatzki, 2008). In contrast, at Komodo Island ( $400 \mathrm{~km}$ south of Spermonde), most acroporids settled between October and April, while pocilloporids and poritids settled all year around (Fox, 2004). Here, the monsoon climate is also similar to Spermonde, however the oceanic conditions are different, leading to stronger variation in SST and generally lower temperatures (Komodo: $\sim 23-28^{\circ} \mathrm{C}$; NASA - Giovanni online 2007-09). This might be responsible for differences in spawning seasonality and consequently explain the differences in recruitment seasonality.

The inter-annual variability in recruitment of this study is consistent with previous findings at several geographic regions (Great Barrier Reef - Dunstan and Johnson, 1998; Indonesia - Fox, 2004; Red Sea - Glassom et al., 2004; Kenya - Mangubhai et al., 2007), which attributes recruitment failures of some corals in some years, 
Table 1

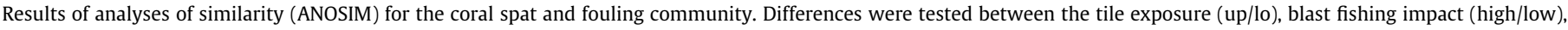

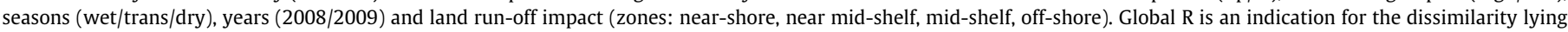
between 0 (equal) and 1 (completely different). All highly significant differences are in bold $(p=0.001)$.

\begin{tabular}{|c|c|c|c|c|c|c|}
\hline Factor & Coral spat community & $R$ & $p$ & Fouling community & $R$ & $p$ \\
\hline Tile exposure & & 0.154 & 0.001 & & 0.843 & 0.001 \\
\hline Bombing impact $^{\mathrm{a}}$ & & 0.001 & 0.320 & & 0.005 & 0.021 \\
\hline \multirow[t]{5}{*}{ Season } & & 0.180 & 0.001 & & 0.032 & 0.001 \\
\hline & Groups & & & Groups & & \\
\hline & Wet $(\mathrm{I}+\mathrm{IV})$ vs. Trans $(\mathrm{II}+\mathrm{V})$ & 0.150 & 0.001 & Wet $(\mathrm{I}+\mathrm{IV})$ vs. Trans $(\mathrm{II}+\mathrm{V})$ & 0.046 & 0.001 \\
\hline & Wet $v s$. Dry (III + VI) & 0.296 & 0.001 & Wet $v s$. Dry $(\mathrm{III}+\mathrm{VI})$ & 0.041 & 0.001 \\
\hline & Trans vs. Dry & 0.092 & 0.001 & Trans vs. Dry & 0.014 & 0.002 \\
\hline Year $^{\mathrm{b}}$ & & 0.005 & 0.072 & & 0.008 & 0.002 \\
\hline \multirow{8}{*}{ Shelf zone (cross-shelf transect) } & & 0.032 & 0.013 & & 0.093 & 0.001 \\
\hline & Groups & & & Groups & & \\
\hline & Near-shore $v s$. Near mid-shelf & 0.063 & 0.016 & Near-shore $v s$. Near mid-shelf & 0.006 & 0.339 \\
\hline & Near-shore $v s$. Far mid-shelf & 0.008 & 0.268 & Near-shore $v s$. Far mid-shelf & 0.140 & 0.001 \\
\hline & Near-shore $v s$. Off-shore & 0.062 & 0.019 & Near-shore $v s$. Off-shore & 0.273 & 0.001 \\
\hline & Near mid-shelf $v s$. Far mid-shelf & 0.026 & 0.067 & Near mid-shelf $v s$. Far mid-shelf & 0.058 & 0.001 \\
\hline & Near mid-shelf $v s$. Off-shore & -0.013 & 0.859 & Near mid-shelf $v s$. Off-shore & 0.156 & 0.001 \\
\hline & Far mid-shelf $v s$. Off-shore & 0.051 & 0.013 & Far mid-shelf $v s$. Off-shore & 0.041 & 0.001 \\
\hline
\end{tabular}

a Without LAE data, since near-shore was only represented by a low bombing impacted reef.

b Without LAE data, since LAE data was available only for the second year.

to variations in larvae survival and dispersal and/or to variation in the abundance of space competitors, for which we have no evidence in Spermonde.

In contrast to the coral spat, a low seasonal variation was found in the fouling community structure on the tiles, despite seasonal variations in river runoff and, hence, nutrient supply (Renema and Troelstra, 2001; Sawall et al., 2012). This could mean that other factors, such as grazers or predators (including herbivorous fishes, but also invertebrates such as echinoids and gastropods) control sessile benthic communities on the tiles. Hence, seasonality in the spat community could hardly be related to the fouling community; except possibly to slightly lower barnacle and bryozoan abundances in the transition and dry season coinciding with higher coral spat abundances. Overall, this suggests that the timing of coral reproduction is unrelated to competition for space in the investigated area, where the abundance of space, and hence, severity of competition, seemed to be more or less constant throughout the year. However, it is known that also surface conditioning, e.g. by biofilms, is important in the context of coral larvae settlement (Webster et al., 2004). The bacterial community structure of biofilms was investigated in a parallel study on the same settlement tiles (but not all sites) (Sawall et al., 2012). Here, a strong seasonality was found, in particular in oligotrophic far mid-shelf reefs, were bacterial diversity (presented as operational taxonomic units) strongly decreased during the driest period of the year, which may suggest preferred coral larvae settlement (this study) on nutrientdepleted biofilms (at any time between June and August). However, further investigations are required to underpin this hypothesis.

\subsection{Spatial variation - blast fishing, eutrophication/pollution}

Reefs with craters of coral rubble and a coral rubble cover of more than $30 \%$ were the hallmarks of blast fishing impacted reefs. This did not always coincide with a reduced live hard coral cover in high compared to low blast impacted reefs, indicating either, a higher pre-blasting coral cover or a predominant blasting of dead substrate at some sites, which infers a continuous larvae supply despite blast fishing. The lack of differences in coral larvae settlement between high and low blast impact reefs is therefore not surprising, even at BTA, where the low live hard coral cover (only $10 \%$ at the beginning of the study) suggests that the much of the settlement is due to allochthonous supply of larvae. While larval supply is an important prerequisite for recovery from disturbance, so is the availability of a stable substrate. In Komodo, recruitment success on natural substrate was low, due to abrasion of already settled coral larvae on moving rubble and due to the abundance of the strongly expanding soft coral Xenia (Fox et al., 2003; Fox, 2004). Also in Spermonde, the presence of coral rubble is strongly elevated in blast fishing impacted reefs. However, also large coral boulders were present (22-26\%), which provide solid settlement space (Harrison and Wallace, 1990; Thongtham and Chansang, 1999) and stabilize coral rubble in between. This might be one of the reasons for the steady increase of live hard coral cover at BTA (10-31\%) and the concomitant decrease of coral rubble, which was particularly high at this site at the beginning of the study (56-42\%). Although blast fishing was still observed at various reefs throughout the study period with varying intensity (personal and colleagues' observations), it did not strike the study sites.

Cross-shelf variability in water quality may partly be natural, but is certainly strongly intensified by human-caused waste water discharge and agriculture activity. Hence, there was a strong change of the algae composition on the upper tiles, shifting from a filamentous towards crustose algae dominated community with distance from shore, in consequence of a eutrophication gradient, as demonstrated elsewhere (Delgado and Lapointe, 1994; Belliveau and Paul, 2002). Furthermore, the near-shore (LAE) spat was almost monopolized by pocilloporids, while all other sites harbored a more diverse coral spat community. The comparatively high settlement on the upper tiles near-shore in contrast to the mid-shelf and off-shore reefs is most likely a response to critically low light levels in these turbid coastal waters (Sammarco, 1991; Maida et al., 1994). Pocilloporids are considered opportunistic corals (Birkeland, 1977; Tomascik, 1991) successfully reproducing in nutrient- and sediment laden waters adverse to other corals (Gilmour, 1999; Harrison and Ward, 2001). They are also able to settle and metamorphose on filamentous algae covered substrates as supported by the results of this study.

With the exception of the near-shore reef, no significant crossshelf change in coral spat community structure was found. Simultaneously, there was hardly any change in the diverse fouling community on the lower tiles. This led to only a low relationship 


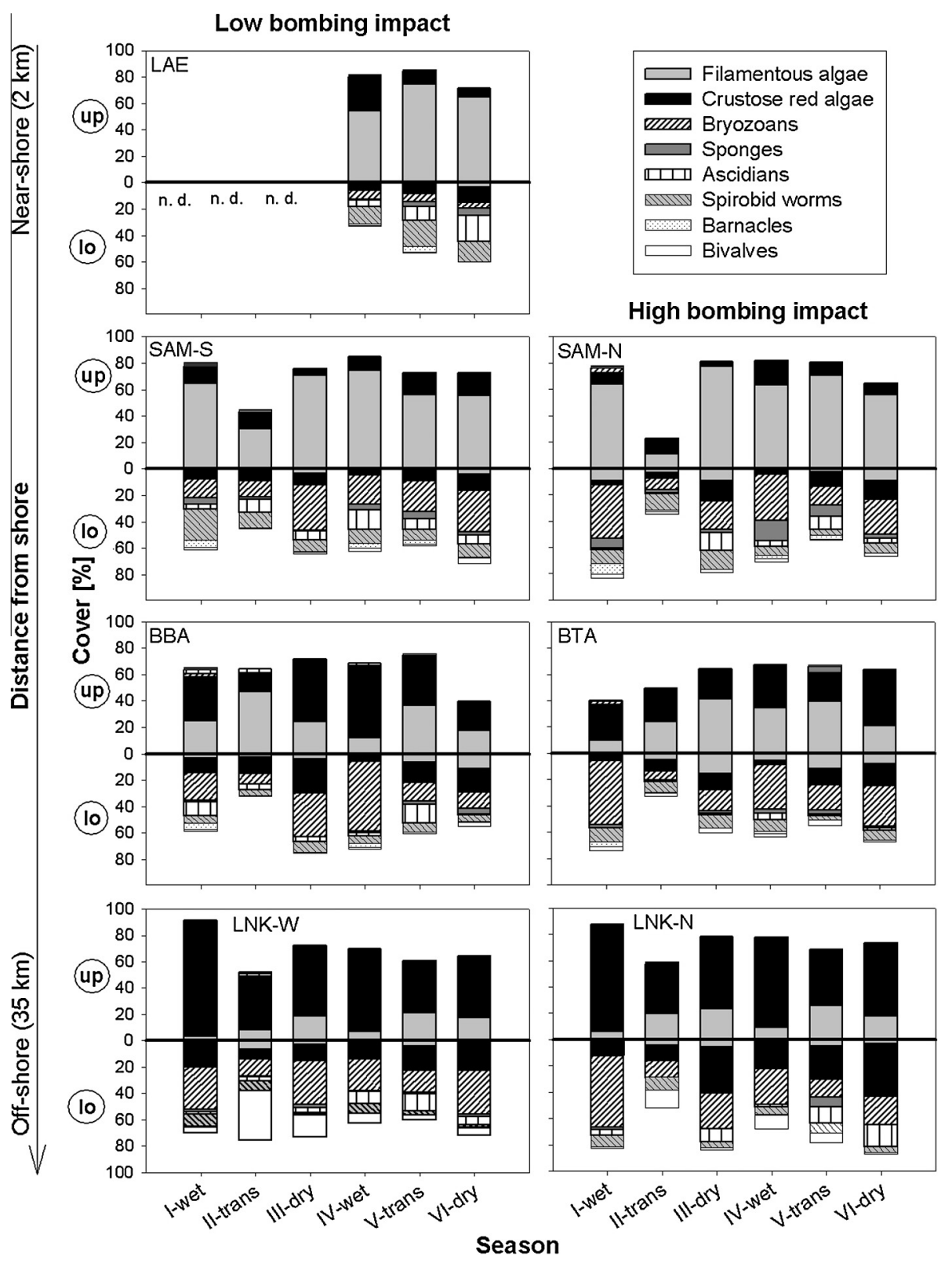

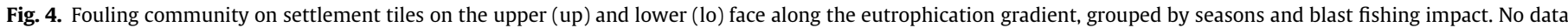
available (n.d.). Counted taxa were converted to\% cover to simplify illustration ( $1 \%$ cover = 5 barnacles, 10 spirorbid worms or 1 bivalvae).

between the coral spat community and the fouling community, which was not possible to assign to cross-shelf effects. Most dramatic changes in the fouling community occurred on the upper tiles, while the coral spat community established predominately on the lower tiles, except near-shore. Therefore, we suggest that initial recruitment rather benefits from the highly heterogeneous 3D-structure formed by diverse fouling organisms on the lower face, comprised by various calcareous organisms (e.g. barnacles, bivalves, spirorbid worms), (Colgan, 1981; Thongtham and Chansang, 1999; Glassom et al., 2004; Petersen et al., 2005), offering suitable substrate for coral larvae settlement.

However, at this point it is not possible to determine possible effects of space competitors and grazers on coral recruits after they grow out of their "hiding" places. Although post-settlement mortality and recruitment on natural substrate was not assessed here, they might be differently affected along the cross-shelf gradient, due to e.g. an increased pressure from space competitors near- shore or near mid-shelf. Those might be severe near-shore, where e. g. various sessile filter-feeders such as ascidians and hydrozoans were found on natural substrate and also off-shore, where macroalgae occurred in increased densities.

\subsection{Oceanographic and management considerations}

Based on the findings in the study, it is suggested that coral larvae supply is still rather high in the Spermonde Archipelago, despite ongoing human activities. Compared to annual recruitment rates in other geographic regions (summarized by Glassom et al., 2004); recruitment rates in Spermonde are intermediate, although comparability is limited, due to differences in substrate sizes (Field et al., 2007) and period of deployment.

For the implementation of management plans it is also important to consider the local current regimes, since currents are mainly responsible for larvae dispersal. Although, we did not 


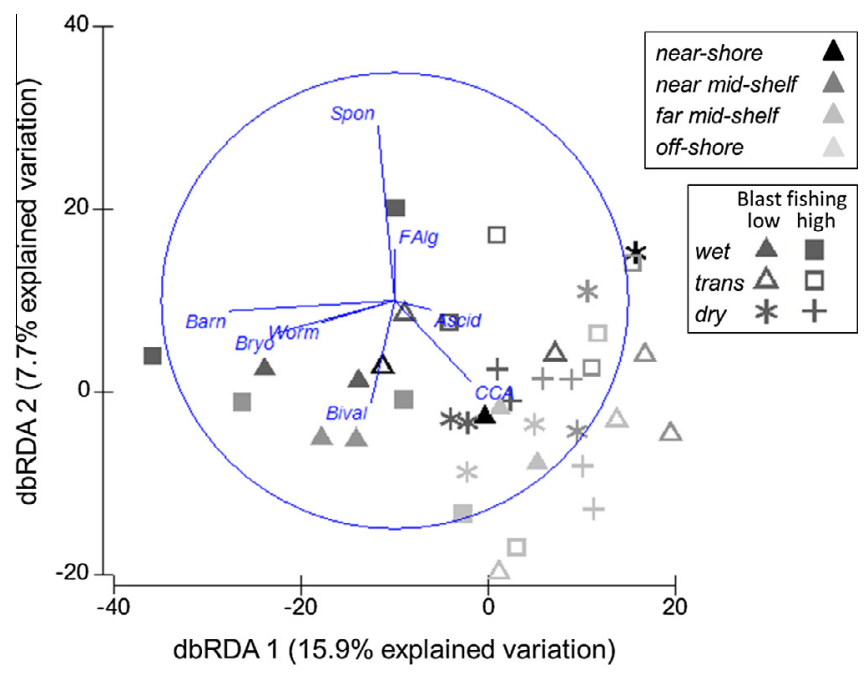

Fig. 5. Distance-based redundancy analysis (dbRDA) with the coral spat community structures as the response variable represented as symbols and the fouling organisms as the predictor variables represented as vectors (FAlg = filamentous algae, $\quad C C A=$ crustose coralline red algae,$\quad$ Barn $=$ barnacles, Worm $=$ spirorbid worms, Bryo = bryozoans, Bival $=$ bivalves, Ascid $=$ ascidians, Spon $=$ sponges $)$. Each symbol represents the spat community of one site at one season ( $n=16$ tile pairs) and the distance between symbols are calculated using Bray-Curtis similarity (resemblance matrix). The length of the vectors relates to the relative importance of a given organism in explaining the spat community structure and the direction points out the course of its increase in abundance.

investigate larval dispersal related to currents, we found indicators for heterogeneous larval dispersal, where live hard coral cover and coral spat densities pointed into opposite direction (e.g. SAM-S: high coral cover, low recruitment; BTA; low coral cover, high recruitment). There is a net transport of water over the Spermonde shelf from $\mathrm{N}$ to $\mathrm{S}$, slightly tilted from NE to SW during the dry season, which suggests a net transport of coral larvae from NE to SW. Additionally, temporal irregularities in current direction and velocity due to winds and tides occur, as well as spatial irregularities due to small eddies formed at the leeside of reefs (Storm, 1989), which needs to be considered by the identification of larvae "source" and "sink" reefs.

However, the success of reef recovery or maintenance of reef functioning in terms of coral recruitment is not only determined by larvae supply and settlement, but also by recruit survival, which is influenced inter alia by anthropogenic water quality degradation. In this study, indications for recruitment success are provided by the composition and abundance of diverse foulers on the tiles and by the composition and dynamics of the benthic cover and led to the following suggestions: (1) The strongly eutrophied near-shore reef LAE featured low coral spat diversity, a high abundance of potential space competitors, such as filamentous algae on settlement tiles and filter-feeders on natural substrate and a low live hard coral cover. Recruitment of diverse coral communities is therefore unlikely and in case of physical destruction, those reefs most likely feature a very low chance of recovery ending in a community dominated by fast growing turf algae and filter feeders. (2) In contrast, near and far mid-shelf reefs (low or no eutrophication impact) seem to be very dynamic, hence featuring a large potential for reef recovery. Coral spat communities were diverse and live coral cover increased substantially at most reefs, including the strongly blast fishing affected reef at far mid-shelf BTA. Availability of solid substrate and low abundance of macroalgae and filter feeders should be supportive for reef recovery. (3) Off-shore reefs also featured diverse coral spat communities and the high abundance of crustose coralline algae might favor fast cementation of loose coral rubble, hence creating suitable substrate for coral larvae settlement. However, strong frondose macroalgae growth, possibly fueled by upwelled nutrients, might hamper recruitment survival. Hence, physical reef destruction might entail longer recovery times.

Generally, reefs in the Spermonde Archipelago seem to be able to buffer some the negative anthropogenic impacts (except strong eutrophication/pollution near-shore) mostly featuring good prerequisites for recovery. Heterogeneous and diverse coral communities are necessary for overexploited fish stocks to recover (e.g. Halford et al., 2004). Without effective management plans and unabated blast fishing and eutrophication the Spermonde reefs are, however, unlikely to sustain the needs of the local population, and risk further and irreversible deterioration.

\section{Acknowledgements}

We want to gratefully acknowledge several students from Hasanuddin University for their great assistance in the field and in logistics. This study was funded by the German Federal Ministry of Education and Research (BMBF, Grant No. 03F0472A) under the bilateral German-Indonesian project Science for the Protection of Indonesian Coastal Ecosystems (SPICE).

\section{Appendix A. Supplementary material}

Supplementary data associated with this article can be found, in the online version, at http://dx.doi.org/10.1016/j.marpolbul.2013. 06.022 .

\section{References}

Abelson, A., Olinky, R., Gaines, S., 2005. Coral recruitment to the reefs of Eilat, Red Sea: temporal and spatial variation, and possible effects of anthropogenic disturbances. Mar. Pollut. Bull. 50, 576-582.

Anderson, M.J., Gorley, R.N., Clarke, K.R., 2008. PERMANOVA+ for PRIMER: Guide to Software and Statistical Methods. PRIMER-E Ltd., Plymouth.

Babcock, R.C., Baird, A.H., Piromvaragorn, S., Thomson, D.P., Willis, B.L., 2003. Identification of scleractinian coral recruits from Indo-Pacific reefs. Zool. Stud. 42, 211-226.

Baird, A.H., Guest, J.R., Willis, B.L., 2009. Systematic and biogeographical patterns in the reproductive biology of scleractinian corals. Annu. Rev. Ecol. Evol. Syst. 40, 551-571.

Belliveau, S.A., Paul, V.J., 2002. Effects of herbivory and nutrients on the early colonization of crustose coralline and fleshy algae. Mar. Ecol. Prog. Ser. 232, 105-114.

Birkeland, C., 1977. The importance of rate of biomass accumulation in early successional stages of benthic communities to the survival of coral recruits. Proc. 3rd Int. Coral Reef Symp. 1, 15-21.

Black, K.P., Gay, S.L., Andrews, J.C., 1990. Residence times of neutrally-buoyant matter such as larvae, sewage or nutrients on coral reefs. Coral Reefs 9, 105114.

Clarke, K.R., Gorley, R.N., 2006. Primer v6: User Manual/Tutorial. PRIMER-E Ltd., Plymouth.

Clarke, K.R., Somerfield, P.J., Chapman, M.G., 2006. On resemblance measures for ecological studies, including taxonomic dissimilarities and a zero-adjusted Bray-Curtis coefficient for denuded assemblages. J. Exp. Mar. Biol. Ecol. 330, 55-80.

Cleary, D.F.B., Becking, L.E., de Voogd, N.J., Renema, W., de Beer, M., von Soest, R.W.M., Hoeksema, B.W., 2005. Variation in the diversity and composition of benthic taxa as a function of distance offshore, depth and exposure in the Spermonde Archipelago, Indonesia. Estuar. Coast. Shelf Sci. 65, 557-570.

Coles, S.L., Brown, E.K., 2007. Twenty-five years of change in coral coverage on a hurricane impacted reef in Hawaii: the importance of recruitment. Coral Reefs 26, 705-717.

Colgan, M.W., 1981. Long-term recovery process of a coral community after a catastrophic disturbance. University of Guam Marine Laboratory: Technical Report 76, pp. 1-69.

Connell, J.H., Hughes, T.P., Wallace, C.C., 1997. A 30-year study of coral abundance, recruitment, and disturbance at several scales in space and time. Ecol. Monogr. 67, 461-488.

Delgado, O., Lapointe, B.E., 1994. Nutrient-limited productivity of calcareous versus fleshy macroalgae in a eutrophic, carbonate-rich tropical marine environment. Coral Reefs 13, 151-159.

Dunstan, P.K., Johnson, C.R., 1998. Spatio-temporal variation in coral recruitment at different scales on Heron Reef, Southern Great Barrier Reef. Coral Reefs 17, 7181. 
Edinger, E.N., Jompa, J., Limmon, G.V., Widjatmoko, W., Risk, M.J., 1998. Reef degradation and coral biodiversity in Indonesia: effects of land-based pollution, destructive fishing practices and changes over time. Mar. Pollut. Bull. 36, 617630.

English, S., Wilkinson, C., Baker, V., 1997. Survey Manual for Tropical Marine Resources. Australian Institute of Marine Science, Townsville, Australia, p. 390.

Ferse, S.C.A., 2008. Artificial reef structures and coral transplantation: fish community responses and effects on coral recruitment in North Sulawesi/ Indonesia. Ph.D. thesis. University of Bremen, p. 169.

Field, S.N., Glassom, D., Bythell, J., 2007. Effects of artificial settlement plate materials and methods of deployment on the sessile epibenthic community development in a tropical environment. Coral Reefs 26, 279-289.

Fox, H.E., 2004. Coral recruitment in blasted and unblasted sites in Indonesia: assessing rehabilitation potential. Mar. Ecol. Prog. Ser. 269, 131-139.

Fox, H.E., Pet, J.S., Dahuri, R., Caldwell, R.L., 2003. Recovery in rubble fields: longterm impacts of blast fishing. Mar. Pollut. Bull. 46, 1024-1031.

Gilmour, J., 1999. Experimental investigation into the effects of suspended sediment on fertilisation, larval survival and settlement in a scleractinian coral. Mar. Biol. $135,451-462$.

Glassom, D., Zakai, D., Chadwick-Furman, N.E., 2004. Coral recruitment: a spatiotemporal analysis along the coastline of Eilat, Northern Red Sea. Mar. Biol. 144, 641-651.

Gleason, M.G., 1996. Coral recruitment in Moorea, Frensh Polynesia: the importance of patch type and temporal variation. J. Exp. Mar. Biol. Ecol. 207, 79-101.

Guest, J.R., Baird, A.H., Goh, B.P.L., Chou, L.M., 2005. Seasonal reproduction in equatorial reef corals. Invertebr. Reprod. Dev. 48, 207-218.

Halford, A., Cheal, A.J., Ryan, D., Williams, D.M., 2004. Resilience to large-scale disturbance in coral and fish assemblages on the Great Barrier Reef. Ecology 85, 1892-1905.

Harriott, V., Fisk, D., 1987. A comparison of settlement plate types for experiments on the recruitment of scleractinian corals. Mar. Ecol. Prog. Ser. 37, 201-208.

Harrison, P.L., Wallace, C.C., 1990. Reproduction, dispersal and recruitment of scleractinian corals. In: Dubinsky, Z. (Ed.), Coral Reefs. Elsevier Science, Amsterdam, pp. 133-207.

Harrison, P.L., Ward, S., 2001. Elevated levels of nitrogen and phosphorus reduce fertilisation success of gametes from scleractinian reef corals. Mar. Biol. 139, 1057-1068.

Hodgson, G., 1990. Sediment and the settlement of larvae of the reef coral Pocillopora damicornis. Coral Reefs 9, 41-43.

Hughes, T.P., Connell, J.H., 1999. Multiple stressors on coral reefs: a long-term perspective. Limnol. Oceanogr. 44, 932-940.

Ilahude, A.G., 1978. On the factors affecting the productivity of the Southern Makassar Strait. Mar. Res. Indonesia 21, 81-107.

Knittweis, L.J.Jompa, Richter, C., Wolff, M., 2009. Population dynamics of the mushroom coral Heliofungia actiniformis in the Spermonde Archipelago, South Sulawesi, Indonesia. Coral Reefs 28, 793-804.

Kuffner, I.B., Paul, V.J., 2004. Effects of the benthic cyanobacterium Lyngbya majuscula on larval recruitment of the reef corals Acropora surculosa and Pocillopora damicornis. Coral Reefs 23, 455-458.

Loya, Y., Lubinevsky, H., Rosenfeld, M., Kramarsky-Winter, E., 2004. Nutrient enrichment caused by in situ fish farms at Eilat, Red Sea is detrimental to coral reproduction. Mar. Pollut. Bull. 49, 344-353.

Maida, M., Coll, J.C., Sammarco, P.W., 1994. Shedding new light on scleractinian coral recruitment. J. Exp. Mar. Biol. Ecol. Ecology 180, 189-202.

Maida, M., Sammarco, P.W., Coll, J.C., 1995. Effects of soft corals on scleractinian coral recruitment. I: Directional allelopathy and inhibition of settlement. Mar. Ecol. Prog. Ser. 121, 191-202.
Mangubhai, S., Harrison, P.L., Obura, D.O., 2007. Pattern of coral larval settlement on lagoon reefs in the Mombasa Marine National Park and Reserve. Kenya. Mar. Ecol. Prog. Ser. 348, 149-159.

Moll, H., 1983. Zonation and diversity of scleractinia on reefs off SW Sulawesi, Indonesia. Ph.D thesis. Leiden University, p. 105.

Petersen, D., Laterveer, M., Schuhmacher, H., 2005. Innovative substrate tiles to spatially control larval settlement in coral culture. Mar. Biol. 146, 937-942.

Pet-Soede, L., Erdmann, M.V., 1998. Blast fishing in Southwest Sulawesi, Indonesia. Naga, ICLARM Q April-June, pp. 4-9.

Pet-Soede, C., Cesar, H.S.J., Pet, J.S., 1999. An economic analysis of blast fishing on Indonesian coral reefs. Environ. Conserv. 26, 83-93.

Renema, W., Troelstra, S.R., 2001. Larger foraminifera distribution on a mesotrophic carbonate shelf in SW Sulawesi (Indonesia). Palaeogeogr. Palaeoclimatol. Palaeoecol. 175, 125-146.

Richmond, R.H., Hunter, C.L., 1990. Reproduction and recruitment of corals: comparison among the Caribbean, the Tropical Pacific and the Red Sea. Mar. Ecol. Prog. Ser. 60, 185-203.

Romatzki, S.B.C., 2008. Reproduction strategies of stony corals (Scleractinia) in an equator near, Indonesian coral reef. Contributions for the reef-restoration. Ph.D. thesis. University of Bremen, p. 94.

Sammarco, P.W., 1991. Geographically specific recruitment and postsettlement mortality as influences on coral communities: the cross-continental shelf transplant experiment. Limnol. Oceanogr. 36, 496-514.

Sammarco, P.W., Andrews, J.C., 1989. The Helix experiment: differential localized dispersal and recruitment patterns in Great Barrier Reef corals. Limnol Oceanogr. 34, 896-912.

Sawall, Y., Phongsuwan, N., Richter, C., 2010. Coral recruitment and recovery after the 2004 Tsunami around the Phi Phi Islands (Krabi Province) and Phuket, Andaman Sea, Thailand. Helgol. Mar. Res. 64, 357-365.

Sawall, Y., Teichberg, M.C., Seemann, J., Litaay, M., Jompa, J., Richter, C., 2011. Nutritional status and metabolism of the coral Stylophora subseriata along a eutrophication gradient in Spermonde Archipelago (Indonesia). Coral Reefs 30 841-853.

Sawall, Y., Richter, C., Ramette, A., 2012. Effects of eutrophication, seasonality and macrofouling on the diversity of bacterial biofilms in equatorial coral reefs. PLoS ONE 7, e39951.

Shlesinger, Y., Loya, Y., 1985. Coral community reproductive patterns: Red Sea versus the Great Barrier Reef. Science 228, 1333-1335.

Storm, C., 1989. A hydrographical survey of a tropical coastal area in the Spermonde Archipelago, South-West Sulawesi, Indonesia. Rapport GEOPRO, Rijksuniversiteit Utrecht, Netherlands.

Tamelander, J., 2002. Coral recruitment following a mass mortality event. Ambio 31 551-557.

Thongtham, N., Chansang, H., 1999. Influence of surface complexity on coral recruitment at Maiton Island, Phuket, Thailand. Res. Bull. Phuket. Mar. Biol. Cent. 20, 93-100.

Tomascik, T., 1991. Settlement patterns of Caribbean scleractinian corals on artificial substrata along a eutrophication gradient, Barbados, West Indies. Mar. Ecol. Prog. Ser. 77, 261-269.

van Woesik, R., 2010. Calm before the spawn: global coral spawning patterns are explained by regional wind fields. Proc. R. Soc. Lond., B 277, 715-722.

Webster, N.S., Smith, L.D., Heyward, A.J., Watts, J.E.M., Webb, R.I., Blackall, L.L., Negri, A.P., 2004. Metamorphosis of a scleractinian coral in response to microbial biofilms. Appl. Environ. Microbiol. 70, 1213-1221.

Willis, B.L., Babcock, R.C., Harrison, P.L., Oliver, J.K., 1985. Patterns in the mass spawning of corals on the Great Barrier Reef from 1981 to 1984. Proc. 5th Int Coral. Reef Symp. 4, 343-348. 